Отже, для того щоб навчальний процес розвивався максимально продуктивно, потрібно оптимізувати навчальне навантаження викладача в напрямі зменшення обсягу групового навчання на користь індивідуально-диференційовано через утворення малих груп слухачів 3 близькими індивідуально-особистісними характеристиками.

У контексті реалізації особистісно зорієнтованого підходу особливого значення набуває ненасильницьке навчання, що дозволяє використовувати психологічні й педагогічні засоби конструктивної взаємодії педагогів і тих, хто навчається, допомагає відійти від авторитарного й маніпулятивного стилю керування на занятті, дозволяє ефективно використовувати різноманітні форми колективної розумової діяльності, що створює сприятливий психологічний мікроклімат, попереджає гіподинамію через різноманітні форми колективної діяльності, сприяє емоційному благополуччю слухачів.

Використовуючи технологію рефлексивного навчання, викладач має можливість відслідковувати у процесі заняття рівень розуміння слухачами навчального матеріалу, особливості їх психологічного стану (ступінь утоми, стомлюваності, зацікавленості), ставлення до навчального матеріалу й заняття в цілому за допомогою налаштування оперативного зворотного зв'язку. Рефлексивне навчання допомагає створити умови для самовираження особистості, ініціює різноманітні види діяльності.

Ефективне застосування технологій особистісно зорієнтованого навчання сприяє створенню здоров'язберігального освітнього середовища.

\title{
Література
}

1. Балл Г. В. Гуманістичні засади педагогічної діяльності: підручник / Г. В. Балл. - К. : Академія. - 1994. - 311 с. 2. Бондаревская Е. В. Гуманистическая парадигма личностно ориентированного образования / Е. В. Бондаревская // Педагогика. - 1997. - № 4. - С. 12-17. 3. Выготский Л. С. Мышление и речь / Л. С. Выготский. - М. : Лабиринт, 2005. - 352 с. 4. Зеер Э. Ф. Личностно ориентированное профессиональное образование/ Э. Ф. Зеер, Г. М. Романцев // Педагогика. - 2002. - № 3. - С. 16-21. 5. Подмазин С. И. Проблемы содержания личностно ориентированного образования / С. И. Подмазин // Завуч. -2001 . - № 11. С. 2-3. б. Севрук А. И. Здоровьезберегающий урок / А. И. Севрук, Е. А. Юнина // Школьные технологи. - 2004. - № 3. - С. 201-202. 7. Якиманська І. С. Технологія особистісно-орієнтованого навчання в сучасній школі / I. С. Якиманська. - М. : Вересень, 2000. - 188 с.

УДК 37.011.3-051

Наталя Поліщук

\section{ВИМОГИ ДО ОСВІТИ ТА ПІДГОТОВКИ ДУХОВНОГО ВЧИТЕЛЯ В ЕПОХУ ІНФОРМАЦЙНО-ВИСОКОТЕХНОЛОГІЧНОГО НАУКОВО-ТЕХНІЧНОГО ПРОГРЕСУ}

Поліщук Н. В. Вимоги до освіти та підготовки духовного вчителя в епоху інформаційно-високотехнологічного науково-технічного прогресу.

У статті розглядаються проблеми трансформації освітньої системи в умовах інформаційно-високотехнологічного суспільства, в якому інформація, знання, технологія розуміються як основні соціальні цінності. Показано, що необхідна модернізація сучасної освіти в контексті підвищення ефективності іiі впливу на професійне самовизначення особистості в системі ринкових та демократичних трансформацій, а також у контексті зростання духовності молоді. 
Ключові слова: освіта, вчитель, молодь, духовність, інформаційновисокотехнологічний науково-технічний прогрес, людство.

Полищук Н. В. Требования к образованию и подготовке духовного учителя в эпоху інформаційно-високотехнологічного научно-технического прогресса.

В статье рассматриваются проблемы трансформации образовательной системы в условиях информационно-высокотехнологического общества, в котором информация, знание, технология выступают в качестве основных социальных ценностей. Показано, что необходима модернизация современного образования в контексте повышения эффективности ее влияния на профессиональное самоопределение личности в системе рыночных и демократических трансформаций, а также в контексте роста духовности молодежи.

Ключевые слова: образование, учитель, молодежь, духовность, информационновысокотехнологический научно-технический прогресс, человечество.

Polishchuk N. V. Requirements for education and training spiritual teacher in the era of information and high-tech science and technology

The articles deals with the issues concerning transforming educational system in conditions of an informational and highly technological society in which information, knowledge and technology represent themselves as the main social values. It is shown, that modernization of modern formation in a context of increase of efficiency of its influence on professional self-determination of the person in system of market and democratic transformations, and also in a context of growth of spirituality of youth is necessary.

Key words: formation, the teacher, youth, spirituality, information-highly technological scientific and technical progress, mankind.

Нині актуальність дослідження стану і перспектив розвитку освіти зростає, оскільки прийшло усвідомлення, що задля розв'язання глобальних проблем, породжених сучасним інформаційно-високотехнологічним науково-технічним прогресом (IBT НТП) і космізацією життєдіяльності суспільства, необхідна нова творча сила, джерелом якої може стати духовний потенціал сучасної молоді та подальше вдосконалення системи освіти. Педагогічна діяльність, напрямлена на зростання цього потенціалу набирає пріоритетного значення, а освіта й духовні вчителі мають стати найважливішими компонентами цієї діяльності. IBT НТП, який розгорнувся в кінці XX і на початку XXI ст., ще більше загострив ці глобальні проблеми. Перехід до інформаційно-високотехнологічного суспільства (IBTC), в якому інформація, знання, технологія розуміються як основні соціальні цінності, означає радикальні зміни в освітній системі. Якою є сутність цих змін? Чи означає перехід до IBTC узагалі й інформатизації та технологізації освіти тріумф технократизму, а чи це вираження тенденції гуманізації суспільного життя? Які перспективи людини і їі освіти в ІВТС? Ці та інші питання активно обговорюються педагогами, філософами, соціологами і футурологами [1; 2].

Освіта протягом усього життя, демократична, безперервна, відновлювана, неформальна, відкрита, випереджаюча, дистанційна та інші іiі новітні форми мають отримати новий розвиток у контексті зростання духовності молоді. Вона має складатися 3 двох підсистем: базова освіта і додаткова, що має здійснюватися протягом всього життя шляхом самостійної освіти. Необхідна модернізація сучасної освіти в контексті спрямування на підвищення ефективності іiї впливу на професійне самовизначення особистості в системі ринкових та демократичних трансформацій. 
Основним чинником цього процесу є цілеспрямована й системно утворююча роль освіти. Для цього необхідним є забезпечення досконалої підготовки вчительських кадрів. Учитель - це людина, яка не тільки отримала спеціальну педагогічну освіту, але яка завжди відчуває себе на вістрі суспільних проблем, який здійснює найважливішу соціальну функцію, забезпечує зв'язок віків і наслідування поколінь, без чого взагалі немислимий прогресивний розвиток людства. Учитель- це мислитель, який відчуває всю повноту покладеної на нього відповідальності за долю ввіреної, яка повірила у нього, Людини, за іiі духовне, інтелектуальне і фізичне здоров'я, за майбутнє своєї країни і всього Світу, всієї людської цивілізації. Цими якостями повинен i, без сумніву, буде володіти вчитель майбутнього, вчитель ХXI століття. Розроблення проблем філософії освіти, Всесвітньої програми «Вчитель», яку можна реалізувати за допомогою сучасних засобів телекомунікації, якраз і зв'язана 3 пошуком найбільш фундаментальних стратегічних основ i пріоритетів розвитку підготовки вчителів, які визначають майбутнє і кожного народу і цивілізації в цілому. Успішне розгортання IBT НТП вимагає відродити високий суспільний статус інженерно-технічної освіти, використання інженерно-технічних i технологічних працівників у суворій відповідальності з їхнім цільовим призначенням. Виробничий потенціал країни в сучасних умовах залежить від ефективного використання найновіших досягнень науки, техніки, технології, інформатики [3].

Сучасний учитель повинен навчати своїх учнів бути відкритими, готовими долати труднощі, орієнтуватися у новітньому технічному, IBTC, постійно самовдосконалюватися та прагнути самореалізації, при цьому постійно замислюватися над тим, які цінності мають слугувати орієнтиром для наступних поколінь. Діяльність у галузі освіти, особливо безпосередня педагогічна діяльність, тісно переплетена з основами світогляду людини. У цьому зв'язку роль учителя в сучасному світі $\epsilon$ вагомою. Незаперечним $\epsilon$ твердження, що саме поняття «вчитель» уже в недалекому майбутньому вийде далеко за рамки цілком професійної діяльності, за рамки деякого ізольованого, замкненого клану. Потреба у нових підходах у системі «освіта - інформація» детермінована також величезним потоком інформації, який збільшується в геометричній прогресії i який погрожує потопити класичну суб'єктивно-об'єктивну систему освіти. I в зв'язку з цим ще більш значимою стає роль вчителя, найважливіше завдання якого - научити жити молоду людину в IBTC, не заблукати у величезному потоці різноманітної інформації, вміти знаходити і використовувати знання. Сучасний аспект інформатизації освіти тісно пов'язаний із визначенням інформатизації суспільства, як засобу його переходу в стан IBTC [2].

Освітня система означається як сукупність факторів, які визначають навчання i розвиток особистості, соціокультурні й економічні умови суспільства, що впливають на освіту, характер інформаційних взаємозв'язків і міжособистісних стосунків, взаємодію з соціальним середовищем. Більше того, в сучасних умовах стабільний економічний і соціокультурний розвиток суспільства неможливий без кваліфікованих освітніх i, головне, духовних кадрів [1]. Професійне самовизначення особистості має здійснюватися у процесі спеціально організованої науково-практичної діяльності професійної орієнтації, котра має розглядатися як система рівноправної взаємодії (через систему освіти та виховання) молодої людини й суспільства, що відповідають особистісним особливостям і запитам ринку праці в конкурентноспроможних кадрах.

$\mathrm{XX}$ ст. позначене не тільки видатними досягненнями в науці, техніці і технології, проривом у космос, незабутні зразки шляхетності і величі людського духу, збагачення культурної спадщини, досягнення в галузі літератури і мистецтва. Воно принесло також глобальні, катастрофічні за своїми наслідками руйнівні катаклізми, війни i 
революції, тоталітаризм і фашизм, реальну загрозу ядерного самознищення i екологічного колапсу, тяжко поправимі деформації морально-духовних ідеалів і цінностей. Це було століття різкої політичної поляризації та економічної могутності і багатства, з одного боку, і жахливої бідності та злиднів, з іншого. Століття все ще непереможених смертоносних хвороб i жахливої неграмотності (біля мільярда людей). Вік свята грубої військової сили, економічного диктату i шантажу, примітивні, розраховані на самі ниці людські інстинкти політики, все ще наявні у багатьох країнах насильства і беззаконня. Вік різкого зростання напруженості в людських взаємовідносинах через непереборену ментальну несумісність людей i співтовариств людей, не говорячи вже про трагічні для людства факти геноциду, реанімації фашизму, тоталітарних і диктаторських політичних режимів, ігнорування елементарних прав людини, репресивного придушення по іншому мислячих людей i їх демократичних свобод. Ідеться в буквальному розумінні про фізичне виживання людства, запобігання незворотної духовно-моральної деградації людства [4]. Водночас мова про байдужість, безвідповідальність, моральну злочинність нинішніх поколінь людей перед поколіннями майбутніми, у спадок яким залишається розрізнений через суперечності і ворожнечу світ, а також сплюндровану природу.

Чи несе свою частку відповідальності освіта за ці вкрай трагічні тенденції в моральній, духовній сфері людської цивілізації, які склалися в ній до кінця XX ст. і ставлять під загрозу саме життя на планеті Земля? Так несе! Сфера освіти, без сумніву, має саме безпосереднє відношення до подій, які відбуваються в світі, в тому числі і до тих негативних тенденцій, які наведені вище, оскільки причиною їх $є$ сама людина, яка втратила здатність активно протистояти Злу у всіх його проявах, яка втратила віру в моральні, духовні цінності світу і сенс людського життя, яка втратила життєві орієнтири і не знаходить відповіді на найважливіші світоглядні питання ні в науці, ні в релігії, ні в освіті. Тільки освіті посильна історична роль у рятівній інтеграції і гармонізації Знання і Віри, в запобіганні незворотних деформацій у менталітеті як локальних спільнот, так і людської цивілізації в цілому, а головне - у відродженні і неперервному збагаченні вищих духовно-моральних ідеалів і життєвих пріоритетів людини. Акцент на духовно-моральний розвиток за гармонійного поєднання 3 емоційним i фізичним, забезпечить бажаний результат, сприяючи формуванню більш успішного i здорового, перш за все душевно i духовно, покоління [4].

Але чи може освіта своїми власними силами вплинути на глобальні, по суті, загальноцивілізаційні, геополітичні процеси? Чи можна розраховувати на те, що освіта в змозі переломити стійкі негативні тенденції і в буквальному розумінні спасти світ від катастрофи, яка неухильно наближається? Може. Але потрібні прориви стратегічного масштабу, необхідно принципово по-новому підходити до обгрунтування й реалізації філософських концепцій, стратегічних орієнтирів і політичних доктрин у сфері освіти, яка перебуає на головному напрямку прориву в достойне майбутнє людської цивілізації, яка здатна знайти переконливу відповідь на виклик цього майбутнього.

Справжня сутність світової освітньої кризи, незважаючи на суперновітні технічні засоби навчання і супернові суто педагогічні ідеї і прийоми в рамках педагогіки XX ст., полягає в безпорадності і неефективності сучасної освіти перед обличчям глобальних проблем цивілізаційного масштабу. Згідно з вимогами XXI ст. педагогіка має стати інформатизованою, технізованою i технологізованою, розкривати позитивні і негативні наслідки IBТ НТП і шляхи нейтралізації останніх.

Звісно, вчителям шкіл, ліцеїв, гімназій і педагогам вищої школи потрібно теж 
змінитися - стати високогуманними, духовними, демократичними у ставленні до дітей і студентів. Система освіти повинна сприяти розвитку природних можливостей кожної людини, спрямовувати іiі на добро, поліпшення життя, на виключення із людських взаємовідносин насилля, ворожості, руйнівного ставлення до природи, до самої людини. Адже необхідно розуміти, що освіта без духовного виховання $\epsilon$ справою безперспективною.

3 настанням XXI ст. людська цивілізація вступила в нову епоху свого розвитку епоху IBTC, що характеризується розгортанням новітнього IBT НТП, швидким поширенням інформаційних технологій, глобалізацією суспільних процесів тощо. Відповідно до цього висуваються нові вимоги до суспільного розвитку у всіх його вимірах. Насамперед необхідна переорієнтація сучасного суспільства на продукування й функціонування саме наукових знань. 3 урахуванням зазначеної тенденції трансформації сучасного суспільства розглядається і якісна своєрідність інноваційного типу особистості. Узагальнюючи та даючи характеристику інноваційній особистості, якою вона має бути в сучасних умовах, виокремимо такі іiі критерії: освіченість; наявність креативних, творчих, нестандартних підходів; емоційна стійкість; готовність до змін; висока мотиваційність; орієнтація на майбутне; комунікабельність. Звісно, нині прогрес в усіх галузях життя настільки стрімкий, що жодна людина не зможе, базуючись лише на отриманій у молодості освіті, ефективно працювати та бути конкурентоспроможною. Тому неперервна освіта («від освіти на все життя, до освіти на протязі всього життя») є визначальною умовою у формуванні повноцінної особистості. У наш час суспільство, як і окрема людина, можуть бути стабільно успішним та ефективним лише перебуваючи в постійних змінах, а значить - у динамічному розвитку. Професійне самовизначення не має зводитися лише до одномоментного вибору, а має бути динамічним процесом, характерним для усіх етапів життя людини, процесом, що здійснюється в системі освіти.

Якщо освіта хоче бути успішною, вона повинна пристосуватися до умов наростання інформаційного вибуху i пришвидшеного розвитку інформаційнокомунікаційних технологій (IКТ), а отже має настати пришвидшення освіти збільшення швидкості освіти протягом одиниці часу. Швидкість освіти - це певна кількість знань, здобутих учнем або студентом за одиницю навчального часу (урок, лекційне чи інше заняття), адже щороку створюється 4 ексабайти (4 $\square 10^{18}$ байт) інформації. Це більше ніж за останні 5000 років. За таких обсягів важливим $є$ уміння знайти та критично сприйняти інформацію. Завдяки впровадженню найновіших технологій, особливо космічних, у багатьох сферах людської діяльності відбувається розвиток за геометричною прогресією. Внаслідок такого інтенсивного розвитку ІКТ освіті також необхідно відповідно пришвидшитися, стати випереджаючою. Тому необхідний як найтісніший взаємозв'язок процесів інформаційного, технічного, технологічного і суспільного прогресу 3 основними тенденціями розвитку системи освіти.

Причиною основного розриву і протиріч всередині соціального організму $\epsilon$ хронічне відставання освітньої системи в справі відтворення духовної і творчої особистості. Відбувається це тому, що освіта не виконує своєї основної функції в суспільстві, яка полягає в тому, що освіта має бути тим перехрестям, де відбувається перехід культури в цивілізацію на рівні масової свідомості, перетворення відірваного від життя знання в практичне, ідеального в конкретний вольовий акт кожної людини. Для того, щоб освіта виявилася здатною виконувати цю найважливішу функцію в суспільстві у повному обсязі, необхідно кардинально змінити іiі філософську 
концепцію в розумінні кого і як виховувати в підростаючому поколінні в XXI i наступних століттях, формувати новий тип особистості - планетарно-космічний за О. Базалуком [1, с. 86-90], або високодуховний космічно-інопланетний (КІП), згідно 3 нашою концепцією (божественний за М. Бердяєвим) [5], як деякого ідеального образу виховного впливу на підростаючі покоління - образу людини майбутнього. До характеристик планетарно-космічної особистості, наведених в [1, с. 86-90], для КІП потрібно додати, що це особистість, яка здатна переселитися і жити в космосі в умовах високорозвиненої КІП цивілізації, спілкуватися і переймати знання та досвід інших КІП високодуховних цивілізацій, бути мудрою, любити Бога, творити на благо людського суспільства, інакше людство чекає катастрофа.

Отже, наповнення авангардних галузей науки й освіти космічним змістом в умовах інтенсивного їх перетворення в безпосередню виробничу силу не обмежує цей процес лише науковим і освітнім пізнанням. Із науки й освіти космічні ідеї починають проникати в інші області пізнавальної і взагалі духовної діяльності, техніковиробничу, соціально-економічну та інші сфери людської діяльності. Уже нині відбувається широке використання космічних чинників і досягнень космонавтики на всіх рівнях і у всіх видах освітньої і виховної діяльності. Космічний напрямок IBT НТП досить інтенсивно впливає на всі сторони життєдіяльності, включаючи і освітню, і духовну складову, людей на Землі [4].

Духовно-моральна криза нині оволоділа всім суспільством i, звичайно, починається вона зі школи і родини. Держава, іiі політикум ніяк не визначаться із морально-духовними цінностями, із трактуванням новітньої історії, не сформовані моральні ідеали, зразки для наслідування. Давно прийшов час підготувати загальнодержавні підходи до формування морально-естетичних цінностей суспільства, молоді. Для будь-якої держави першочерговим загальнодержавного масштабу завданням мусить бути проблема педагогічної освіти, підготовки вчителя, привабливості його професії, формування поваги суспільства до нього. Педагогічна освіта мусить розв'язати дві головні проблеми - широкої педагогічної освіти всього населення, яка необхідна нині кожному дорослому. Друга проблема - це виховання майбутнього високодуховного Вчителя, взагалі, Педагога. Професія вчителя має бути святою на Землі, а не рабською, жебрацькою і бюрократичною. Елвін Тоффлер, видатний американський політолог, економіст, називав найефективнішою ту державу, економіка якої базується на нових знаннях, нових університетах 3 потужними лабораторно-дослідницьким і науковими комплексами. Поки що ми йдемо зворотнім шляхом. Мусимо ситуацію виправити. Лише прискорене ефективне реформування системи освіти, всебічне підвищення iї якісного рівня до міжнародних стандартів, іiі суспільно-державного статусу, авторитету здатне спричинити прискорений розвиток України, добробут і щастя ㄲi народу в XXI ст. Отже, на сучасному етапі IBT НTП і розвитку суспільства освіта і духовний учитель, взагалі, педагог, який здійснює освітню діяльність, являються найвагомішою сферою життєдіяльності людства.

\section{Література}

1. Базалук О. А. Философия образования. Формирование планетарнокосмического типа личности / О. А. Базалук // Образ человека будущего: Кого и Как воспитывать в подрастающих поколениях: [коллективная монография]/ под. ред. О. А. Базалука. - К. : Кондор, 2011. - Т. 1. - С. 61-93. 2. Поліщук Н. В. Філософськоосвітні та духовні перспективи науково-технічного розвитку цивілізації в епоху інформаційно-високотехнологічного прогресу / Н. В. Поліщук// Сб. науч. трудов SWorld. - Иваново : Маркова А. Д. - 2013. - Вып. 3. - Том 30. - С. 83-95. - ЦИТ:3130150. 3. Урсул А. Д. Информатизация общества и переход к устойчивому развитию 
цивилизации / А. Д. Урсул // Вестник РОИВТ. - 1993. - № 1-2. - С. 35-45. 4. Поліщук Н. В. Науково-технічний прогрес i духовно-моральне становлення молоді: [монографія] / Н. В. Поліщук - Рівне : О. Зень, 2012. - 464 с. 5. Поліщук Н. В. Філософсько-освітні перспективи пізнання Всесвіту та виховання духовних людей космічно-інопланетного майбутнього / Н. В. Поліщук // Философия и космологія / Philosophy Cosmology 2013. - Киев, 2014. - С. 190-200.

УДК 378.147 .88

Любов Продан

\section{ПІДГОТОВКА МАЙБУТНЬОГО СУЧАСНОГО ВЧИТЕЛЯ ПОЧАТКОВИХ КЛАСІВ ЗАСОБАМИ КРАЕЗНАВЧОГО МУЗЕЮ}

Продан Л. А. Підготовка майбутнього сучасного вчителя початкових класів засобами краєзнавчого музею.

У статті йдеться про шляхи успішної професійної підготовки вчителів початкових класів засобами краєзнавчого музею. Охарактеризовано види роботи у краєзнавчому музеї ВН3, які використовуються викладачами під час роботи зі студентами. 3'ясовано значення краєзнавчого музею у формуванні особистості вчителя. Досліджено, які завдання пробуджують у студентів інтерес до краєзнавчої роботи, розвивають у них дослідницькі навички, ініціативу та творчість.

Ключові слова: краєзнавчий музей, краєзнавча педагогіка, підготовка майбутнього вчителя, дослідницька робота.

Продан Л. А. Подготовка будущего современного учителя младших классов средствами краеведческого музея.

В статье говорится о путях успешной профессиональной подготовки учителей начальных классов средствами краеведческого музея. Охарактеризованы виды работы в краеведческом музее вузов, которые используются преподавателями во время работы со студентами. Исследовано, какие задачи пробуждают в студентах интерес к краеведческой работе, развивают в них исследовательские навыки, инициативу и творчество.

Ключевые слова: краеведческий музей, краеведческая педагогика, подготовка будущего учителя, исследовательская работа.

Prodan L. A. Training the future primary school teacher by addressing materials of local history museum.

The article discusses ways of successful professional training of primary school teachers in the context of addressing materials of local history museum. The author characterizes kinds of work to be done in universities' local history museums which students accompanied by their university teachers attend. The article clarifies what tasks motivate students' interest in local history, develop their research skills, initiative and creativity.

Key words: local history museum, history education, training of future teachers, research work.

Ефективність реалізації завдань реформування освіти, спрямованих на виховання національно свідомих і освічених громадян України, багато в чому залежить від краєзнавчої підготовки сучасного майбутнього вчителя початкової школи та його обізнаності в роботі краєзнавчого музею.

Краєзнавчий музей, як ефективний шлях створення культуротворчого 